九州大学学術情報リポジトリ

Kyushu University Institutional Repository

\title{
Spatial Connection of Vegetable Market in Cambodia
}

\author{
Em, Huy \\ Department of Agro-Industry, MAFF \\ Yutaka, Tomoyuki \\ Faculty of Agriculture, Kyushu University \\ Fukuda, Susumu \\ Faculty of Agriculture, Kyushu University \\ Kai, Satoshi \\ Faculty of Agriculture, Kyushu University
}

https://doi.org/10.5109/9337

出版情報: 九州大学大学院農学研究院紀要. 52 (2)，pp.465-474，2007-10-29. Faculty of Agriculture, Kyushu University

バージョン：

権利関係 : 


\title{
Spatial Connection of Vegetable Market in Cambodia
}

\author{
Huy EM${ }^{1}$, Tomoyuki YUTAKA, Susumu FUKUDA \\ and Satoshi KAI*
}

\author{
Laboratory of Food Marketing, Division of Industrial Organization of Agribusiness, \\ Department of Agricultural and Resource Economics, Faculty of Agriculture, \\ Kyushu University, Fukuoka 812-8581, Japan \\ (Received June 30, 2007 and accepted July 17, 2007)
}

\begin{abstract}
Using monthly prices data of five categories of vegetables selected from 11 markets, this paper investigates the co-price movement of vegetables at wholesale level from 2002 to 2006. Timmer's model (1986) is applied in this study to test the degree of market connection. The empirical results show that most of regional markets studied are well connected in long run with Deum Kor, the central vegetable market whereas the number of markets which are connected in short run decrease. Few markets are poorly interrelated with the central market, and tend to be separated. However, the degree of market connection varies depending on commodities and locations where markets are located. Road, communication, and market information network are induced as vital factors, which produce market segmentation in this country. Moreover, certain markets are also influenced by exogenous factors, including harvest, draught, water shortage, and flood on their price formation.
\end{abstract}

\section{INTRODUCTION}

Cambodia is one of developing nations, its economy mostly relies on the agricultural sector, which is the backbone of about 80 percent of lives. To capture Cambodian economic policy, the three remarkable phases are briefly stressed since 1979. Firstly, the central planning period starts from 1979 till 1989. Its ruling system and economy at that time based on communism block (Sophal Ear, 1995). State owned and determined everything. The excessive centralization of the planning, control and management of agriculture, inappropriate price policies, and defective incentive systems for agricultural operators that supply inputs to agriculture and that market, transport, and process farm products are the major factors, which create technical deficiencies (Johnson, 1983). Technical efficiency is the ability of the firm to produce the maximum output from its resources (Karl D. Skold and Victor N. Popov, 1990).

Secondly, 1990 to 1993 is the liberalization period. The tendency towards free market economic began since communism collapsed. The State of Cambodia then had less control on every sector, and its assets such as land were initially privatized. The reforming is a positive trend toward technical efficiency. Lastly, the free market economic period starts from 1994 up to now after a Paris Agreement, which paved the way for United Nations to hold a national election in 1993 since Cambodia had fallen in tragedy war and social turmoil for over 20 years. The new government was formed in 1994 to lead the country basing on western leading style. Peace and positive direction to development were secured along with a reformation of many fields to cope with a free market economic orientation. The influence of the central planning ideology remains in the free

\footnotetext{
1 Department of Agro-Industry, MAFF, Cambodia.

* Corresponding author (E-mail: satokai@agr.kyushu-u.ac.jp)
}

market performances though. Insufficient particular laws and regulations, poor infrastructures, poor institutions are still major concerns. The improving agricultural sector until now has been seen working very slowly to response the market reforming. Most of farmers still face many problems in their farming career and stay in a poor living standard. Frequently in developing nations, regional markets are not well integrated, and transport and communication are commonly difficult and expensive (Paul J. Heytens, 1986). This shows a picture of poor distribution of information for example in Cambodian market environment. Eugene F. Fama (1976) said "In an efficient market, prices 'fully reflect' available information".

The surplus and deficit often occurred at almost every region in Cambodia, and have created a situation of food insecurity, which eventually results in an unequal distribution of economic growth among farmer households, and allows the price fluctuation to emerge in the agricultural market (Prabhakara Rao J. V., 1985). Prices appear different from one to another market because transportation and transaction costs (Barry K. Goodwin and Ted C. Schroeder, 1991). The price fluctuations vary depending entirely on crops, regions, and time. Among the causes affecting the degree of market connection, availability of market information and transportation costs are the main common factors. Therefore, the degree of agricultural market connection is a crucial determent of agricultural price policy. Considered as an incentive to greater production and as an insurance against the vagaries of the market, price policy is the key player in promoting agricultural production (J. V. Prabhakara RAO, 1985). Because of its necessity to agricultural policy, concept of market integration becomes crucial for the developing nations (Carol Alexander and John Wyeth, 1994). In the economic sense, markets are said to be spatially integrated when the price in the deficient/importing market is equal to the price in the surplus/exporting market plus 
the marketing costs for moving the given product between the two (Ravallion, 1986). Moreover, markets have to be efficient and preferably unbiased to allow future markets to play in a risk management and/or price stabilization (A. J. Aulton, et al., 1997).

The main objectives of this study are to analyze the pattern of price fluctuations across the markets, and to examine whether movements of prices in the different markets for the same commodity are separated or synchronized in Cambodian vegetable markets.

The rest of the paper will be organized as follows. Section two deals with data description, section three is about econometric specification, section four talks about the empirical result, and lastly it comes to conclusion, and policy implication section.

\section{DATA DESCRIPTION}

To achieve the above goal, we gathered wholesale prices of five categories of vegetables on monthly bases from 11 markets (Fig. 1) in 11 provinces/cities throughout Cambodia. Those markets include Serey Sophorn, Bung Chhouk, Leu (Kampong Chhnang), Deum Kor, Leu (Kampong Som), Samaki, Doun Keo, Takhmao, Nak Loeung, Bung Kok, and Leu (Siem Reap) (Table 1). This monthly price data is obtained from marketing office of Ministry of Agriculture, Forestry, and Fisheries

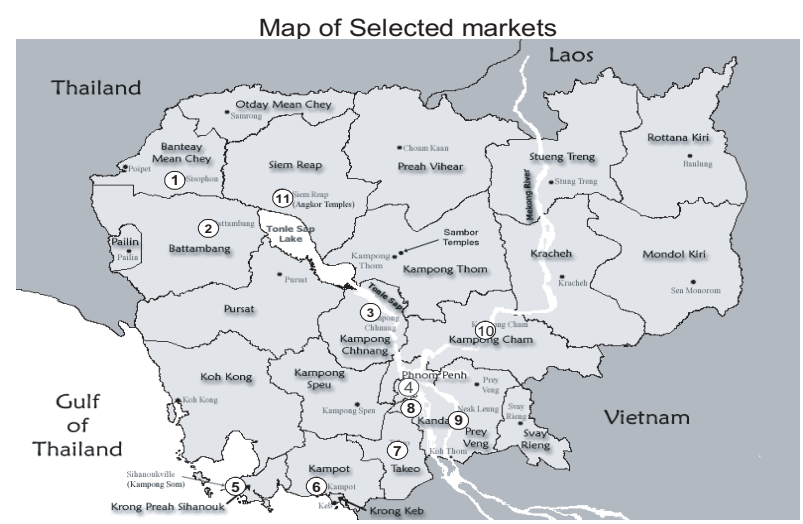

Fig. 1. Location of vegetable markets selected for study.
(MAFF), Cambodia in 2006. There are two reasons to select these markets and commodities for our study. One is due to the market significant share in the regional distribution of production, and secondly due to availability of data. Few missing observations appear in certain markets but they are replaced by the average of the same months of the sample period to make our data processing and analysis go smoothly.

Currently there are no real wholesale markets and auction system existing in this country. The markets existing at the moment called in Cambodian language "Phsar" are seen to be conglomerate. The transaction is done basing on a direction negotiation. Because of its important role in collecting and distributing, Deum Kor, locating in Phnom Penh capital city, is widely considered as the biggest vegetable market in Cambodia (Chan Sipana and Paule Moustier, 2004). This market is functioning as consumption and distribution. Bung Kok, Nak Loeung, Doun Keo, and Samaki are located in the regions where their borders are shared with Vietnam. So, the trade across the border must influence their price formation, whereas Serey Sophorn and Bung Chhouk come under the same condition because of the border of their location shared with Thailand.

As you can see them in the figure 2, 3, 4, 5, and 6, the movements of vegetables prices in Cambodia seem to follow the same pattern from one to another year.

Table 1. List of markets selected for study

\begin{tabular}{rllc}
\hline $\begin{array}{c}\text { Serial } \\
\text { No. }\end{array}$ & \multicolumn{1}{c}{$\begin{array}{c}\text { Name of } \\
\text { Markets }\end{array}$} & \multicolumn{1}{c}{ Province } & Remarks \\
\hline 1 & Serey Sophorn & Banteay Mean Chey & Regional Market \\
2 & Bung Chhouk & Battam Bang & $/ /$ \\
3 & Leu & Kampong Chhnang & // \\
4 & Deum Kor* & Phnom Penh & Rentral market \\
5 & Leu & Kampong Som & Regional Market \\
6 & Samaki & Kampot & $/ /$ \\
7 & Dounkeo & Takeo & $/ /$ \\
8 & Takhmao & Kandal & // \\
9 & Bung Kok & Kampong Cham & Prey Vegng \\
10 & Nak Loeung & Prem Reap & \\
11 & Leu & Siem & \\
\hline
\end{tabular}

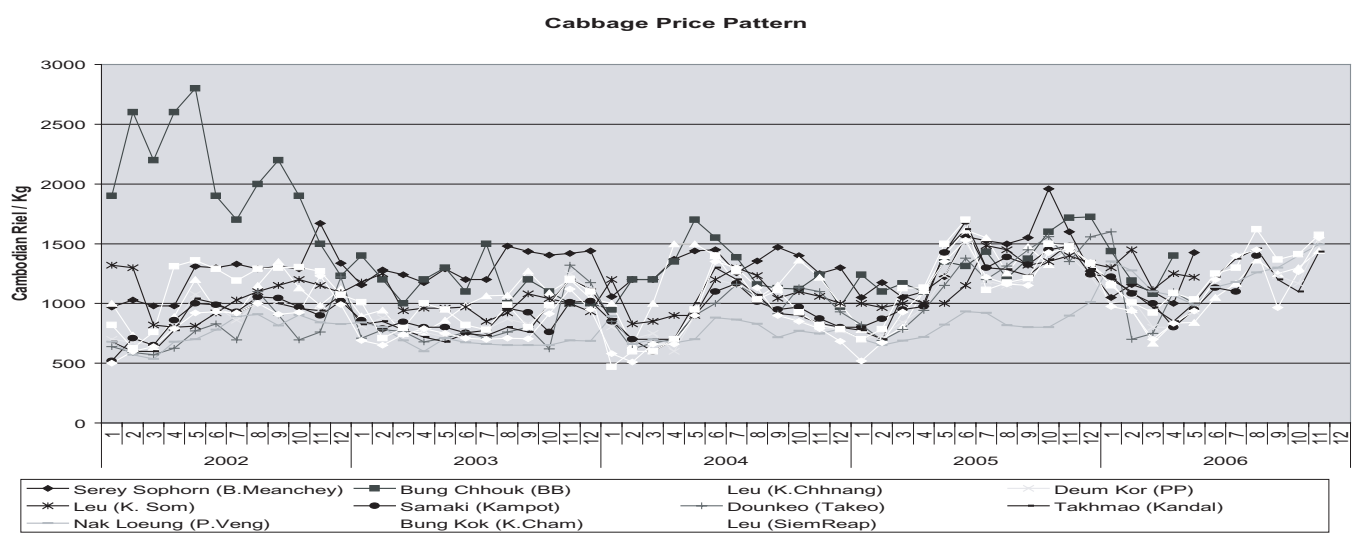

Fig. 2. Cabbage price pattern at 11 markets. 


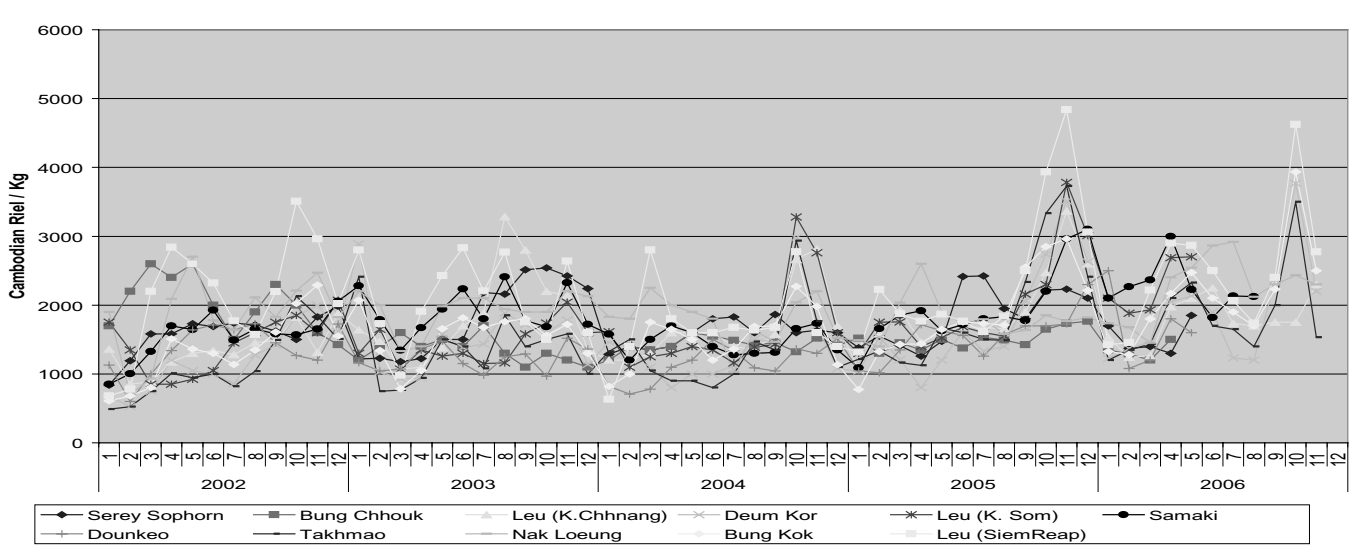

Fig. 3. Chinese Kale price pattern at 11 markets.

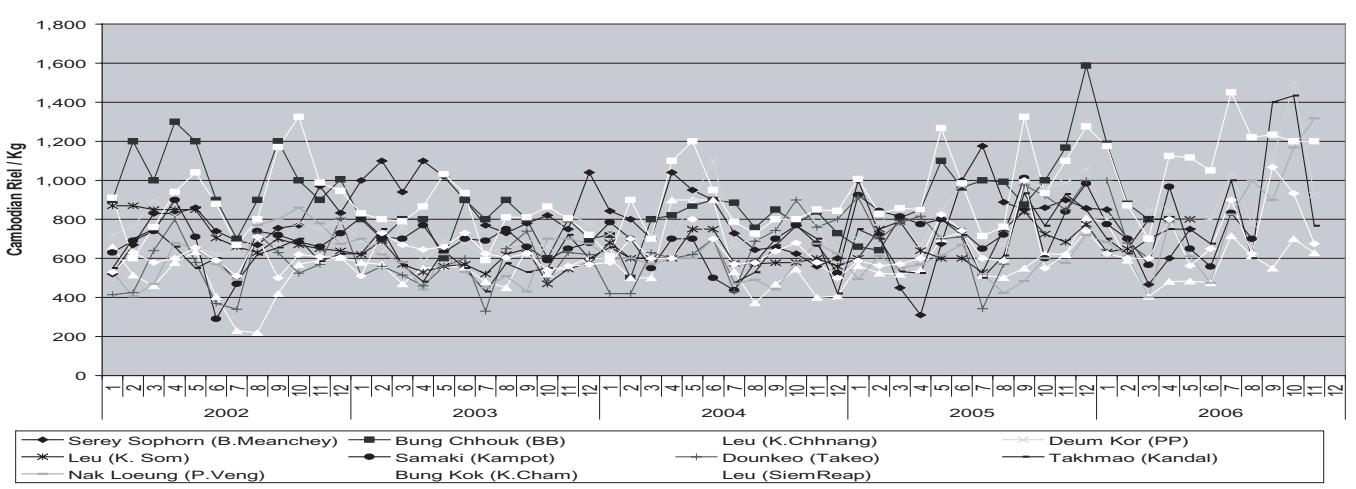

Fig. 4. Cucumber price pattern at 11 markets.

Radish Price Pattern

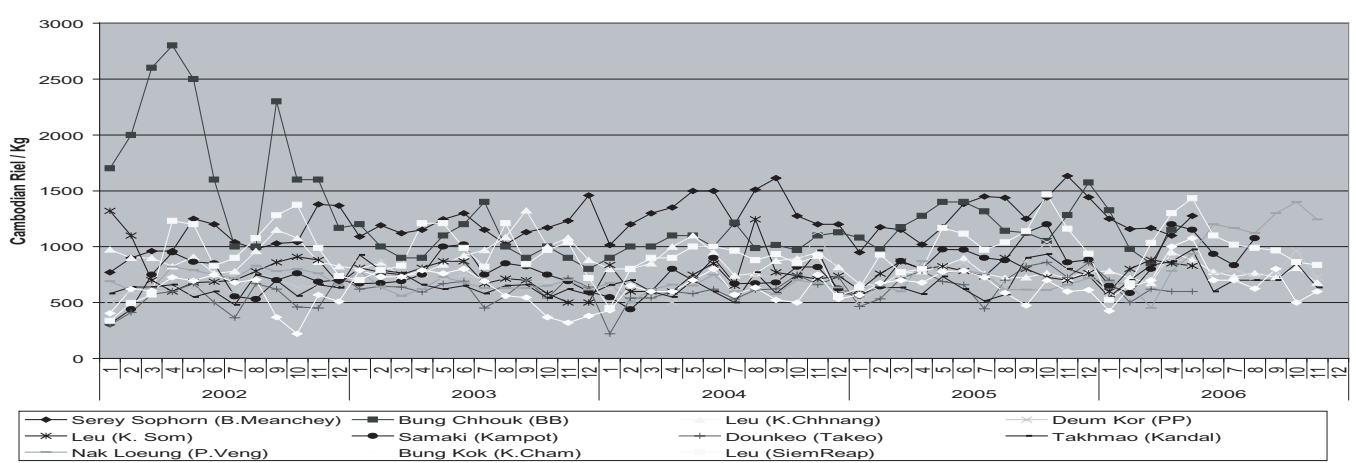

Fig. 5. Radish price pattern at 11 markets.

Tomato Price Pattern

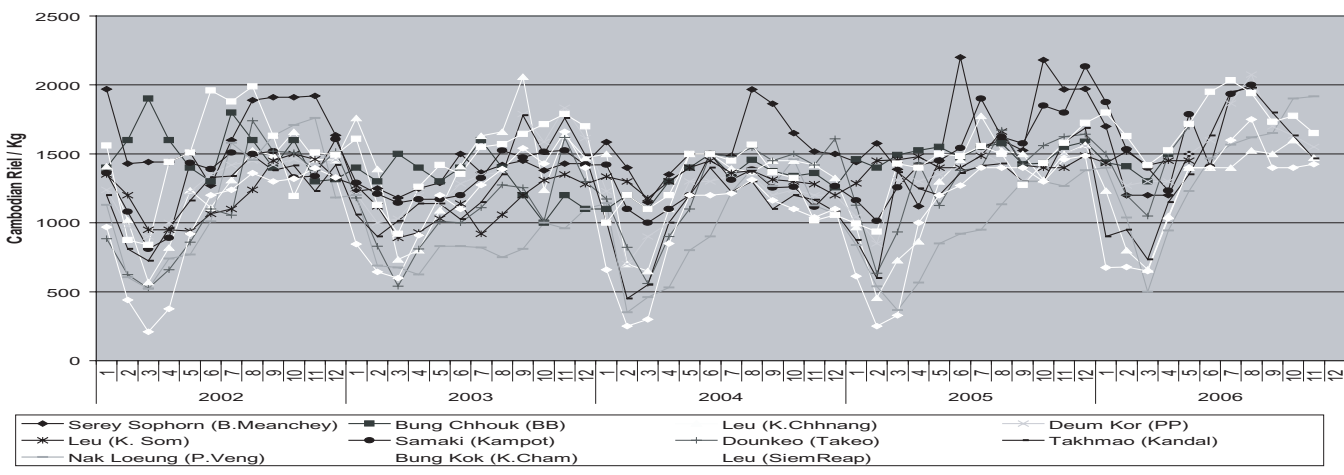

Fig. 6. Tomato price pattern at 11 markets. 
Commonly prices start increasing dramatically in September, and reach on the peak in November, in which most of markets face shortage of supplies, and then the curves begin descending from December and to the lowest point around February and/or March, during which markets come under harvest season.

\section{ECONOMETRIC SPECIFICATION}

It can be said that the central market (Deum Kor) is the main vegetable price formation in Cambodia. Therefore, Vegetable price information flows from the central market to the local market, The vegetable prices between local and central market are connected, and spatial market integration can be short-term and/or long-term. One hypothesizes that the vegetable price change at local market is independent from the vegetable price change at the central market, the local and central market are not well connected in the short run, and the local and central market are separated in the long run.

The model used in this chapter was pioneered by Timmer in 1986 to test the performance of corn market in Indonesia (Timmer C. P., 1987). Two different markets, regional and central are involved in this model. The main concept of the model is that if these two markets are integrated, the adjustment of price at the regional market will be made in order to respond to the price change in the central market. This model attempts to test the degree of short-run and long-run connection between the central market and regional markets. Here is the econometric model of dynamic version:

$$
\begin{aligned}
P_{t}^{l}-P_{t-1}^{l}= & \boldsymbol{\alpha}_{0}+\boldsymbol{\alpha}_{1}\left(P_{t-1}^{l}-P_{t-1}^{c}\right)+\boldsymbol{\alpha}_{2}\left(P_{t}^{c}-P_{t-1}^{c}\right)+\boldsymbol{\alpha}_{3} P_{t-1}^{c} \\
& +\boldsymbol{\beta} X+\epsilon
\end{aligned}
$$

Where $P_{t}^{l}$ : the logarithm of price of commodity at time $t$ of local markets

$P_{t}^{c}$ : the logarithm of price of commodity at time $t$ of central markets

$X$ : the vector of exogenous influences on local markets

$\boldsymbol{\alpha}_{i}, \boldsymbol{\beta}$ : parameters to be estimated

$\epsilon$ : disturbance term

From the equation (1), the price change at the local market depends on the lagged price change between local and central market $P_{t-1}^{l}-P_{t-1}^{c}$, the price change at central market $P_{t}^{c}-P_{t-1}^{c}$, the lagged price of central market $P_{t-1}^{c}$, and a vector of exogenous influences $X$.

Because there is a difficulty to handle the equation (1) to separate the short-run and the long-run effects of the central market on the local market, the equation (1) can be transformed as follows:

$$
\begin{aligned}
P_{t}^{l}= & \boldsymbol{\alpha}_{0}+\left(1+\boldsymbol{\alpha}_{1}\right) P_{t-1}^{l}+\boldsymbol{\alpha}_{2}\left(P_{t}^{c}-P_{t-1}^{c}\right)+\left(\boldsymbol{\alpha}_{3}-\boldsymbol{\alpha}_{1}\right) P_{t-1}^{c} \\
& +\boldsymbol{\beta} X+\epsilon
\end{aligned}
$$

Where $\boldsymbol{\alpha}_{0}$ : the coefficient of intercept, $1-\boldsymbol{\alpha}_{1}$ : the contribution of the lagged price of local market to the formation of the current price of local market, $\boldsymbol{\alpha}_{3}-\boldsymbol{\alpha}_{1}$ : the contribution of the lagged price of central market to the formation of the current price of local market, $\boldsymbol{\alpha}_{2}$ : the coefficient which measures the transmission of the change in price of central market to the current local price in long-run market connection.

In the equation (2), price formation at time $t$ at local market is determined by the lagged price of local market, the change in price of central market, the lagged price of central market, and the vector of exogenous influences. An index of market connection (IMC) can be developed from the equation (2). IMC is the ratio between the contribution of the lagged price of local market to the formation of the current local price and the contribution of the lagged price of central market to the formation of the current price of local market. The value of IMC shows the degree of market integration. Index of Market Connection (IMC)

$$
I M C=\frac{1+\boldsymbol{\alpha}_{1}}{\boldsymbol{\alpha}_{3}-\boldsymbol{\alpha}_{1}}
$$

\section{Benchmark for valuating market connection}

If/IMC/ $<1$, it indicates the strong connection between the markets in short run or in other word, one can say the central market contributes more than the local previous price to form the local current price in the short run. If/IMC/ $>1$, it indicates the poor connection between the markets in short run.

To capture the seasonality in vegetable production, four dummy variables, which are non-price influences on the regional markets, were selected to include into the model. The dummy variables selected conceive of main harvest season, draught, water shortage, and flood factor. Because we have chosen 10 different regional markets to be studied, therefore the condition of applying the dummy variables to those markets varies basing on the geographical location, and annual reports of Ministry of Agriculture, Forestry, and Fisheries of Cambodia. During the period of time that these non-price influences occur, the dummy takes value 1 and zero elsewhere.

\section{Hypothesis testing}

- Markets are said to be segmented if the estimates of $\boldsymbol{\alpha}_{3}-\boldsymbol{\alpha}_{1}$ and $\boldsymbol{\alpha}_{2}$ are statistically insignificant.

- Markets are said to be connected in short run if the estimate of $\boldsymbol{\alpha}_{3}-\boldsymbol{\alpha}_{1}$ is statistically significant.

- Market are said to be connected in long run if the estimate of $\boldsymbol{a}_{2}$ is statistically significant.

\section{EMPIRICAL RESULTS AND DISCUSSION}

\section{Spatial market connection at wholesale level}

The measurement of market connection can be viewed as the basic data for an understanding of how specific markets work (Ravallion, 1986). Spatial market connection consists of two types, short and long run, which are brought to be discussed as follows. The discussion will be related to 5 commodities at 10 different local markets (dependent variable) and one central mar- 
Table 2. Index of Market Connection

\begin{tabular}{lcccrr}
\hline & Cabbage & Chinese Kale & Cucumber & Radish & Tomato \\
\hline Dem Kor-Serey Sophorn & 1.48 & 1.45 & 2.33 & 1.86 & 3.98 \\
Deum Kor-Bung Chhouk & 2.62 & 21.22 & 0.36 & 5.78 & 761 \\
Deum Kor-Leu (K. Chhnang) & 2.02 & 1.28 & 1.28 & 3.04 & 15.73 \\
Deum Kor-Leu (K. Som) & 86.12 & 0.82 & 1.11 & 1.65 & 10.54 \\
Deum Kor-Samaki & 0.37 & 0.61 & 1.31 & 0.79 & 1.34 \\
Deum Kor-Doun Keo & 1.78 & 1.66 & 1.6 & 0.69 & 3.28 \\
Deum Kor-Takhmao & 0.25 & 0.25 & 0.05 & 0.04 & 0.81 \\
Deum Kor-Nak Loeung & 4.53 & 91.8 & 34.8 & 8.95 & 8.16 \\
Deum Kor-Bung Kok & 0.57 & 0.12 & 0.49 & 0.99 & 3.54 \\
Deum Kor-Leu (Siem Reap) & 1.00 & 0.73 & 0.46 & 1.93 & 1.03 \\
\hline
\end{tabular}

ket (independent variable). The estimated coefficients of independent price variables in the price formation equation represent the responsiveness (elasticity) of vegetable prices at the local markets. Again, Ravallion argues that the acceptance of short-run restrictions implies long-run market integration but that the reverse is not true. This concept is true to what we found in this study.

\section{Short-run connection at wholesale level - Cabbage}

Table 2 indicates that Takhmao, Samiki, and Bung Kok market are well connected with Deum Kor market in the short run for cabbage with index of market connection $0.25,0.37$, and 0.57 respectively. The low index 0.25 between Takhmao and Deum Kor market suggests that Deum Kor strongly contributes to the price formation of Takhmao. This is because Takhmao stays very close to Deum Kor with the good road connection and communication networks. So the price adjustment at Takhmao market quickly responds to the change in price of Deum Kor market. On the other hand, Deum Kor functions both as the consumption part and distribution center and has a purchasing power, so most of supplies which are traded into this market are not only to meet its own demand but for redistribution to other markets as well. In contrast, Serey Sophorn, Dounkeo, Leu (Kampong Chhnang), Bung Chhouk, Nak Loeung, and Leu market (Kampong Som) are poorly connected with Deum Kor in short run. It suggests that these markets have strongly relied on their own previous prices and other exogenous influences rather than Deum Kor, the central market in forming their current prices. In the case of Serey Sophorn and Bung Chhouk market, they both may import cabbage from Thailand whereas Doun Keo and Nak Loeung may have a trade linkage with Vietnam. For Leu market (Kampong Som), this market may have received added cabbage supplies from the nearest markets such as Samaki in short-run adjustment.

\section{- Chinese Kale}

Table 2 shows that Deum Kor contributes more than the regional previous prices to form the current prices of certain regional markets, including Bung Kok, Takhmao, Samaki, Leu (Siem Reap), and Leu (Kampong Som) for
Chinese Kale. The evidence of low indices of market connection between the paired markets suggests that they both are well connected in the short run. Among these regional markets, Bung Kok and Takhmao have received stronger influences from Deum Kor because these two regional markets stay in the main production areas, which consist of many potential collectors, who have regular connection with Deum Kor, the road connection and communication network between the two are good and shorter in distance. In contrast, Leu (Kampong Chhnang), Serey Sophorn, Dounkeo, Bung Chhouk, and Nak Loeung are very poorly connected with Deum Kor. These markets tend to strongly rely on their own past prices and other sources rather than the central past prices in forming their current prices. The poor connection suggests that these markets have received Chinese Kale from additional sources to meet the shortage period in the short-run adjustment.

\section{- Cucumber}

Table 2 shows that Takhmao, Bung Chhouk, Leu (Siem Reap), and Bung Kok are well connected in the short run with Deum Kor. The low indices can be interpreted that Deum Kor market contributes more than the regional past prices to form the current prices of those regional markets. The reasons behind the good connection between Deum Kor and Takhmao for cucumber are the same as already explained in the case of Chinese Kale. However the connection in the short run between Deum Kor and Bung Chhouk appears strange in the case of cucumber because Bung Chhouk tends to be independent from Deum Kor for most of the commodities selected for study. One may suggest that the trade between the two may be done only in the case of cucumber in short-run connection among those five commodities selected or may be due to any indirect intermarket. In the opposite, the poor connection in the short run between Deum Kor and other regional markets, including Leu (Kampong Som), Leu (Kampong Chhnang), Samaki, Serey Sophorn, and Nak Loeung market suggests that these markets have strongly relied on their own previous prices and other additional sources.

\section{- Radish}

Table 2 shows that there are four markets, including Samaki, Doun Keo, Takhmao, and Bung Kok that have 
Table 3. Results of estimated coefficients of cabbage price formation equation for 10 local markets

\begin{tabular}{lcccccccccc}
\hline Variables & $\mathrm{M}^{\mathrm{a}}$ & $\mathrm{M} 2$ & $\mathrm{M} 3$ & $\mathrm{M} 5$ & $\mathrm{M} 6$ & $\mathrm{M} 7$ & $\mathrm{M} 8$ & $\mathrm{M} 9$ & $\mathrm{M} 10$ & $\mathrm{M} 11$ \\
\hline Intercept & -0.403 & 0.011 & 0.415 & 2.177 & 0.494 & 1.668 & 0.489 & 1.503 & 0.927 & 0.541 \\
& $(-0.39)^{\mathrm{b}}$ & $(0.01)$ & $(0.69)$ & $(2.31)$ & $(1.11)$ & $(2.98)$ & $(1.81)$ & $(2.30)$ & $(2.51)$ & $(1.20)$ \\
$\mathrm{P}^{l}{ }_{\mathrm{t}-1}$ & $0.619^{* *}$ & $0.692^{* *}$ & $0.626^{* *}$ & $0.689^{* *}$ & $0.251^{*}$ & $0.485^{* *}$ & 0.185 & $0.643^{* *}$ & $0.315^{* *}$ & $0.459^{* *}$ \\
& $(5.60)$ & $(6.92)$ & $(6.09)$ & $(5.33)$ & $(1.86)$ & $(3.45)$ & $(1.35)$ & $(5.72)$ & $(2.67)$ & $(4.32)$ \\
$\mathrm{P}^{\mathrm{c}}{ }_{\mathrm{t}}-\mathrm{P}^{\mathrm{c}}{ }_{\mathrm{t}-1}$ & $0.561^{* *}$ & 0.123 & $0.426^{* *}$ & 0.211 & $0.823^{* *}$ & $0.387^{* *}$ & $0.875^{* *}$ & $0.476^{* *}$ & $0.603^{* *}$ & $0.473^{* *}$ \\
$\mathrm{P}^{\mathrm{c}}{ }_{\mathrm{t}-1}$ & $(3.61)$ & $(0.93)$ & $(4.36)$ & $(1.06)$ & $(8.07)$ & $(4.46)$ & $(15.76)$ & $(2.59)$ & $(10.43)$ & $(6.86)$ \\
& $0.419^{*}$ & $0.293^{*}$ & $0.309^{* *}$ & -0.008 & $0.674^{* *}$ & $0.272^{*}$ & $0.745^{* *}$ & 0.142 & $0.554^{* *}$ & $0.457^{* *}$ \\
& $(2.35)$ & $(2.10)$ & $(2.95)$ & $(-0.04)$ & $(5.00)$ & $(2.33)$ & $(5.86)$ & $(1.27)$ & $(6.16)$ & $(5.18)$ \\
\hline $\mathrm{F}-$ value & 20.78 & 15.91 & 40.88 & 19.65 & 73.24 & 32.51 & 174.05 & 29.82 & 136.57 & 72.46 \\
$\mathrm{R}^{2}$ & 0.6388 & 0.5805 & 0.6943 & 0.5512 & 0.8116 & 0.6701 & 0.9293 & 0.6236 & 0.8835 & 0.8010 \\
\hline
\end{tabular}

“*” the significant at $\mathbf{Q}=5 \%$, and “**” the significant at $\mathbf{Q}=1 \%$

(a): M1 = Serey Sophorn market, M2 = Bung Chhouk market, M3 = Leu market $($ K. Chhnang, M4 = Deum Kor market, M5 = Leu market (K. Som), M6 = Samaki market, M7 = Doun Keo market, M8 = Takhmao market, M9 = Nak Loeung market, M10 = Bung Kok market, M11 = Leu market (Siem Reap). (b) : Figures in parentheses are $t$-value

significantly relied on the past prices of Deum Kor market in forming their current prices. It can be said that these markets are well connected with Deum Kor in short run for radish. For instance the low index 0.04 of Takhmao indicates that the degree of connection between this market and Deum Kor is very strong. The same reasons as mentioned in the case of Chinese Kale and cucumber are implied for this good connection. In contrast, Serey Sophorn, Bung Chhouk, Leu (Kampong Chhnang), Leu (Kampong Som), Nak Loeung, and Leu (Siem Reap) have not depended on the past prices of Deum Kor but on their own previous prices and other sources instead in order to form their current radish prices. These markets show their poor connection with Deum Kor in short run.

\section{- Tomato}

The results of IMC in table 2 reveal that most of regional markets are poorly connected in the short run with Deum Kor market for tomato, except one. That is Takhmao market with the IMC 0.81. It can say that though Takhmao has depended on its previous prices, the reliance on the central historical prices to form its current price is even significantly stronger. The reason behind the poor connection between Deum Kor and other regional markets in short run for tomato may be because tomato is one of local commodities, which can be produced every regions throughout the country. Other reason is probably tomato is partly imported. Therefore tomato trade between markets has rarely been done in the short term but long term in stead.

\section{Long-run connection at wholesale level}

Markets are said to be connected in long run, if the estimate of $\boldsymbol{\alpha}_{2}$ is statistically significant. If the condition holds, one can say that a unit change in the central price is passed on fully in the regional prices in respond.

\section{- Cabbage}

Table 3 shows that Serey Sophorn, Leu (Kampong Chhnang), Samaki, Doun Keo, Takhmao, Nak Loeung,
Bung Kok, and Leu (Siem Reap) are significantly well connected in the long run with Deum Kor. The strong connection between those markets with Deum Kor market because Deum Kor is the main wholesale market place for not only consumption but also distribution. Another reason is that cabbage is mostly imported from Vietnam. Samaki and Takhamo show their stronger connection than other markets in the long run with Deum Kor with the estimated coefficient 0.82 and 0.87 . From the sense of price responsiveness or elasticity, we can say one percent change in price at Deum Kor leads to 0.82 and 0.87 percent change in price at Samaki and Takhmao respectively in respond. However, the long-run connection appeared between Deum Kor and Serey Sophorn is a rare case because these two markets tend to be segmented for other four crops selected in both short and long run. Thus, the good connection in the long run between the two for cabbage may happen by chance or indirect transaction.

Note that there are no dummy variables applied in the equation of price formation of cabbage to capture other exogenous factors because cabbage is the imported product.

\section{- Chinese Kale}

Table 4 shows that Leu (Kampong Chhnang), Leu (Kampong Som), Samaki, Takhmao, Nak Loeung, Bung Kok, and Leu (Siem Reap) are well connected in the long run with Deum Kor market. The degree of the connection is significantly very strong, and the change in price at Deum Kor is fully passed on the Chinese Kale price formation of those market in their long-run market adjustment. In the opposite, Serey Sophorn, Bung Chhouk, and Doun Keo market are poorly connected with Deum Kor market in the long run in the case of Chinese Kale.

In addition, harvest, draught, water shortage, and flood period are also the major factors, which have influenced on the price formation of certain regional markets studied. In general, prices of agricultural products drop down during harvest season and the estimated coeffi- 
cients are assumed to take a negative sign. The prices relatively increase, and the estimated coefficients take a positive sign when production encounters any natural disasters, including draught, water shortage, or flood, etc.

We found that Serey Sophorn, Bung Chhouk, Samaki, Doun Keo, and Bung Kok have been under the influence of harvest season with the estimated coefficients $-0.22,-0.24,-0.19,-0.24$, and 0.21 respectively. As mentioned above, the prices during harvest season normally decrease that why the estimated coefficients take negative sign but as you see here the result of the estimated coefficient of Chinese Kale for Bung Kok appears positive in stead. The positive value (0.21) tells us that though during harvest season, the price of Chinese Kale in Bung Kok is still high and increases up to $21 \%$. The increase in price suggests that most of Chinese Kale produced in this area were traded to the central market or elsewhere, and then it resulted in shortage of Chinese Kale supplies for that local market consumption. The impact of harvest season can be induced that these markets are located in Chinese Kale production areas. Besides, Samaki and Leu (Siem Reap) have been significantly under the influence of draught and water shortage while Bung Chhouk and Nak Loeung have been under the influence of water shortage only. However all of the estimated coefficients take the negative sign, that is opposite from the above statement. The negative values of these estimated coefficients indicate that the current price of Chinese Kale of those markets decrease. The reason is that though the areas where the markets are located faced draught and/or water shortage, they even still received over supplies of Chinese Kale, which eventually make price decrease.
Therefore, we see these factors do not contribute in any increase in price at the present time but in deed in the following one or two months they may do.

\section{- Cucumber}

Table 5 indicates that the marketing system for cucumber is well connected in the long run at the wholesale level. The markets that have been influenced by the price change at Deum Kor market include Bung Chhouk, Leu (Kampong Chhnang), Leu (Kampong Som), Samaki, Doun Keo, Takhmao, Nak Loeung, Bung Kok, and Leu (Siem Reap). The influence from Deum Kor on the above regional markets reflect the long-run connection between Deum Kor and those regional markets. Among these markets, Takhmao, Bung Kok, and Samaki appear to have a stronger connection than the others while Serey Sophorn tends to be poorly connected with Deum Kor in the long run for cucumber.

Harvest and draught period have also influenced on certain regional markets in the cucumber price formation. Samaki, Doun Keo, Takhmao, and Leu (Siem Reap) are impacted by harvest season whereas Doun Keo and Leu (Siem Reap) faced the impact of draught. On the other hand, from the impact of harvest season we may conclude that these markets are located in the cucumber production areas. The similar explanation of the impact of harvest season and draught come to cucumber.

\section{- Radish}

Table 6 shows that marketing system at wholesale level is mostly well connected in the long run for radish. Leu (Kampong Chhnang), Leu (Kampong Som), Samaki, Doun Keo, Takhmao, Bung Kok, and Leu (Siem Reap)

Table 4. Results of estimated coefficients of Chinese Kale price formation equation for 10 local markets

\begin{tabular}{|c|c|c|c|c|c|c|c|c|c|c|}
\hline Variables & $\mathrm{M}^{\mathrm{a}}$ & M2 & M3 & M5 & M6 & M7 & M8 & M9 & M10 & M11 \\
\hline Intercept & $\begin{array}{c}1.593 \\
(0.78)^{\mathrm{b}}\end{array}$ & $\begin{array}{c}3.688 \\
(1.12)\end{array}$ & $\begin{array}{l}2.374 \\
(2.22)\end{array}$ & $\begin{array}{l}1.385 \\
(1.40)\end{array}$ & $\begin{array}{l}0.817 \\
(0.70)\end{array}$ & $\begin{array}{l}1.742 \\
(1.22)\end{array}$ & $\begin{array}{l}0.505 \\
(1.19)\end{array}$ & $\begin{array}{l}4.056 \\
(3.09)\end{array}$ & $\begin{array}{l}0.220 \\
(0.30)\end{array}$ & $\begin{array}{l}1.134 \\
(1.38)\end{array}$ \\
\hline $\mathrm{P}_{\mathrm{t}-1}^{\mathrm{l}}$ & $\begin{array}{c}0.467^{* *} \\
(3.47)\end{array}$ & $\begin{array}{c}0.488^{* *} \\
(3.60)\end{array}$ & $\begin{array}{c}0.375 * * \\
(2.87)\end{array}$ & $\begin{array}{l}0.364 \\
(2.62)\end{array}$ & $\begin{array}{c}0.336^{* *} \\
(2.40)\end{array}$ & $\begin{array}{c}0.488^{* *} \\
(3.60)\end{array}$ & $\begin{array}{c}0.187 \\
(1.28)\end{array}$ & $\begin{array}{c}0.459 * * \\
(3.95)\end{array}$ & $\begin{array}{c}0.100 \\
(0.71)\end{array}$ & $\begin{array}{c}0.353^{* *} \\
(2.76)\end{array}$ \\
\hline $\mathrm{P}_{\mathrm{t}}^{c}-\mathrm{P}_{\mathrm{t}-1}^{c}$ & $\begin{array}{l}-0.076 \\
(-0.26)\end{array}$ & $\begin{array}{l}-0.110 \\
(-0.30)\end{array}$ & $\begin{array}{c}0.747 * * \\
(3.92)\end{array}$ & $\begin{array}{l}0.608^{*} \\
(3.32)\end{array}$ & $\begin{array}{c}0.776^{* *} \\
(3.59)\end{array}$ & $\begin{array}{c}0.116 \\
(0.56)\end{array}$ & $\begin{array}{l}0.844^{* *} \\
(12.73)\end{array}$ & $\begin{array}{c}0.463 * * \\
(2.52)\end{array}$ & $\begin{array}{c}0.991^{* *} \\
(7.15)\end{array}$ & $\begin{array}{c}0.569 * * \\
(5.27)\end{array}$ \\
\hline $\mathrm{P}_{\mathrm{t}-1}^{c}$ & $\begin{array}{l}0.321 \\
(1.14)\end{array}$ & $\begin{array}{c}0.023 \\
(0.06)\end{array}$ & $\begin{array}{l}0.292 \\
(1.44)\end{array}$ & $\begin{array}{c}0.441^{* *} \\
(2.43)\end{array}$ & $\begin{array}{c}0.552^{* *} \\
(2.56)\end{array}$ & $\begin{array}{c}0.293 \\
(1.38)\end{array}$ & $\begin{array}{c}0.754^{* *} \\
(5.59)\end{array}$ & $\begin{array}{l}-0.005 \\
(-0.03)\end{array}$ & $\begin{array}{c}0.852^{* *} \\
(4.75)\end{array}$ & $\begin{array}{c}0.482^{* *} \\
(3.32)\end{array}$ \\
\hline Harvest & $\begin{array}{c}-0.216^{*} \\
(-1.78)\end{array}$ & $\begin{array}{c}-0.240^{*} \\
(-2.18)\end{array}$ & $\begin{array}{l}0.023 \\
(0.22)\end{array}$ & $\begin{array}{l}-0.116 \\
(-1.19)\end{array}$ & $\begin{array}{c}-0.187^{*} \\
(-2.05)\end{array}$ & $\begin{array}{c}-0.244^{*} \\
(-2.14)\end{array}$ & $\begin{array}{l}-0.019 \\
(-0.37)\end{array}$ & $\begin{array}{l}-0.126 \\
(-1.17)\end{array}$ & $\begin{array}{l}0.206^{*} \\
(2.19)\end{array}$ & $\begin{array}{l}-0.066 \\
(-0.70)\end{array}$ \\
\hline Draught & $\begin{array}{l}-0.174 \\
(-0.73)\end{array}$ & $\begin{array}{l}-0.153 \\
(-0.59)\end{array}$ & $\begin{array}{l}-0.122 \\
(-0.93)\end{array}$ & & $\begin{array}{l}-0.243 \\
(-1.88)\end{array}$ & $\begin{array}{l}-0.150 \\
(-1.18)\end{array}$ & $\begin{array}{l}-0.054 \\
(-0.82)\end{array}$ & $\begin{array}{l}-0.177 \\
(-1.35)\end{array}$ & $\begin{array}{c}0.003 \\
(0.04)\end{array}$ & $\begin{array}{l}-0.218 \\
(-1.81)\end{array}$ \\
\hline $\begin{array}{l}\text { Water } \\
\text { shortage } \\
\text { Flood }\end{array}$ & $\begin{array}{l}-0.106 \\
(-0.83)\end{array}$ & $\begin{array}{l}-0.213^{*} \\
(-1.83)\end{array}$ & $\begin{array}{l}-0.100 \\
(-1.00) \\
0.238^{*} \\
(2.33)\end{array}$ & & $\begin{array}{c}-0.259 * * \\
(-2.70)\end{array}$ & $\begin{array}{l}-0.072 \\
(-0.56) \\
-0.009 \\
(-0.04)\end{array}$ & $\begin{array}{c}-0.069 \\
(-1.35) \\
0.011 \\
(0.19)\end{array}$ & $\begin{array}{c}-0.233^{*} \\
(-2.11) \\
0.222^{*} \\
(2.00)\end{array}$ & $\begin{array}{c}-0.105 \\
(-1.38) \\
0.131 \\
(1.42)\end{array}$ & $\begin{array}{c}-0.253^{* *} \\
(-2.95)\end{array}$ \\
\hline F-value & 5.75 & 4.94 & 13.12 & 13.01 & 11.09 & 5.39 & 57.80 & 10.91 & 24.22 & 17.01 \\
\hline $\mathrm{R}^{2}$ & 0.4776 & 0.4458 & 0.6476 & 0.5255 & 0.5809 & 0.4616 & 0.9042 & 0.6044 & 0.7723 & 0.6668 \\
\hline
\end{tabular}

"*” the significant at $\mathbf{Q}=5 \%$, and "**" the significant at $\mathbf{Q}=1 \%$

(a): M1 = Serey Sophorn market, M2 = Bung Chhouk market, M3 = Leu market (K. Chhnang, M4= Deum Kor market M5 = Leu market (K. Som),

M6 = Samaki market, M7 = Doun Keo market, M8= Takhmao market, M9= Nak Loeung market, M10= Bung Kok market, M11 = Leu market (Siem Reap).

(b): Figures in parentheses are t-value 
Table 5. Results of estimated coefficients of cucumber price formation equation for 10 local markets

\begin{tabular}{|c|c|c|c|c|c|c|c|c|c|c|}
\hline Variables & $\mathrm{M}^{\mathrm{a}}$ & M2 & M3 & M5 & M6 & M7 & M8 & M9 & M10 & M11 \\
\hline Intercept & 3.847 & 3.815 & 3.138 & 2.245 & 2.517 & 3.249 & 1.022 & 4.283 & 0.350 & 1.961 \\
\hline & $(3.11)^{\mathrm{b}}$ & $(3.40)$ & (3.94) & $(2.12)$ & (2.47) & (3.91) & (1.89) & $(4.18)$ & $(0.34)$ & (2.03) \\
\hline$P_{t-1}^{1}$ & $0.296^{*}$ & 0.111 & $0.305^{*}$ & $0.353^{* *}$ & $0.358^{* *}$ & $0.320^{*}$ & -0.047 & $0.348^{* *}$ & $0.318^{* *}$ & 0.224 \\
\hline $\mathrm{P}^{\mathrm{c}}-\mathrm{P}^{\mathrm{c}}$ & (1.88) & $\begin{array}{l}(0.60) \\
0.351 *\end{array}$ & $\begin{array}{l}(2.37) \\
0.238 *\end{array}$ & $\begin{array}{l}(2.61) \\
0559 * *\end{array}$ & $\begin{array}{l}(2.60) \\
(302 * *\end{array}$ & $\begin{array}{l}(2.29) \\
\text { (2.2) }\end{array}$ & $(-0.40)$ & (2.49) & $(2.62)$ & $(1.44)$ \\
\hline $1 t^{t} 1 t^{t}-1$ & $(1.37)$ & $(2.14)$ & $\begin{array}{l}0.238 \\
(2.17)\end{array}$ & $\begin{array}{l}0.55 y^{w-1} \\
(3.34)\end{array}$ & $\begin{array}{c}0.302 \\
(3.11)\end{array}$ & $\begin{array}{l}0.231 \\
(3.03)\end{array}$ & $\begin{array}{l}0.615^{2 *} \\
(11.32)\end{array}$ & $\begin{array}{l}0.207^{*} \\
(1.84)\end{array}$ & $\begin{array}{c}0.586^{* *} \\
(5.28)\end{array}$ & $\begin{array}{c}0.344 \\
(2.99)\end{array}$ \\
\hline $\mathrm{P}_{\mathrm{t}-1}^{\mathrm{c}}$ & $\begin{array}{l}0.127 \\
(0.98)\end{array}$ & $\begin{array}{l}0.311^{*} \\
(1.81)\end{array}$ & $\begin{array}{l}0.239 * \\
(2.31)\end{array}$ & $\begin{array}{l}0.317^{*} \\
(2.15)\end{array}$ & $\begin{array}{l}0.274^{*} \\
(1.90)\end{array}$ & $\begin{array}{l}0.200^{*} \\
(2.22)\end{array}$ & $\begin{array}{c}0.916^{* *} \\
(8.57)\end{array}$ & $\begin{array}{l}0.010 \\
(0.08)\end{array}$ & $\begin{array}{c}0.649^{* *} \\
(3.51)\end{array}$ & $\begin{array}{c}0.482 * * \\
(3.43)\end{array}$ \\
\hline Harvest & $\begin{array}{l}-0.042 \\
(-0.65)\end{array}$ & $\begin{array}{l}-0.046 \\
(-0.73)\end{array}$ & $\begin{array}{l}-0.099 \\
(-1.63)\end{array}$ & $\begin{array}{l}-0.066 \\
(-1.49)\end{array}$ & $\begin{array}{l}-0.118^{*} \\
(-2.33)\end{array}$ & $\begin{array}{l}-0.084^{*} \\
(-1.73)\end{array}$ & $\begin{array}{c}-0.080 * * \\
(-2.66)\end{array}$ & $\begin{array}{l}-0.060 \\
(-1.01)\end{array}$ & $\begin{array}{l}-0.032 \\
(-0.64)\end{array}$ & $\begin{array}{l}-0.122 * \\
(-2.23)\end{array}$ \\
\hline Draught & $\begin{array}{l}-0.014 \\
(-0.11)\end{array}$ & $\begin{array}{l}-0.095 \\
(-0.47)\end{array}$ & $\begin{array}{l}-0.081 \\
(-0.99)\end{array}$ & & $\begin{array}{l}-0.098 \\
(-1.26)\end{array}$ & $\begin{array}{l}-0.092 * \\
(-1.73)\end{array}$ & $\begin{array}{l}0.034 \\
(0.85)\end{array}$ & $\begin{array}{l}-0.085 \\
(-1.11)\end{array}$ & $\begin{array}{l}-0.094 \\
(-1.66)\end{array}$ & $\begin{array}{l}-0.134^{*} \\
(-1.71)\end{array}$ \\
\hline $\begin{array}{l}\text { Water } \\
\text { shortage }\end{array}$ & $\begin{array}{l}0.039 \\
(0.62)\end{array}$ & $\begin{array}{l}-0.011 \\
(-0.18)\end{array}$ & $\begin{array}{l}-0.036 \\
(-0.61)\end{array}$ & & $\begin{array}{l}-0.049 \\
(-1.02)\end{array}$ & $\begin{array}{c}0.029 \\
(0.58)\end{array}$ & $\begin{array}{l}-0.007 \\
(-0.23)\end{array}$ & $\begin{array}{l}-0.019 \\
(-0.32)\end{array}$ & $\begin{array}{l}-0.011 \\
(-0.25)\end{array}$ & $\begin{array}{l}-0.065 \\
(-1.17)\end{array}$ \\
\hline Flood & & & $\begin{array}{c}0.092 \\
(1.33)\end{array}$ & & & $\begin{array}{l}-0.032 \\
(-0.32)\end{array}$ & $\begin{array}{l}-0.027 \\
(-0.84)\end{array}$ & $\begin{array}{l}0.045 \\
(0.67)\end{array}$ & $\begin{array}{l}0.091 \\
(1.63)\end{array}$ & \\
\hline $\mathrm{F}$-value & 1.20 & 1.83 & 4.53 & 5.36 & 3.71 & 4.1 & 25.11 & 2.57 & 10.63 & 6.38 \\
\hline $\mathrm{R}^{2}$ & 0.1894 & 0.2682 & 0.3881 & 0.3134 & 0.3165 & 0.3979 & 0.8104 & 0.2725 & 0.5981 & 0.4709 \\
\hline
\end{tabular}

"** the significant at $\mathbf{Q}=5 \%$, and "**" the significant at $\mathbf{Q}=1 \%$

(a): M1 = Serey Sophorn market, M2 = Bung Chhouk market, M3 = Leu market (K. Chhnang, M4 = Deum Kor market, M5 = Leu market (K. Som), M6 = Samaki market, M7 = Doun Keo market, M8 = Takhmao market, M9= Nak Loeung market, M10 = Bung Kok market, M11 = Leu market (Siem Reap).

(b): Figures in parentheses are $t$-value

Table 6. Results of estimated coefficients of radish price formation equation for 10 local markets

\begin{tabular}{|c|c|c|c|c|c|c|c|c|c|c|}
\hline Variables & $\mathrm{M}^{\mathrm{a}}$ & M2 & M3 & M5 & M6 & M7 & M8 & M9 & M10 & M11 \\
\hline Intercept & $\begin{array}{c}4.138 \\
(2.65)^{\mathrm{b}}\end{array}$ & $\begin{array}{l}5.367 \\
(4.24)\end{array}$ & $\begin{array}{c}4.898 \\
(3.63)\end{array}$ & $\begin{array}{l}1.966 \\
(1.64)\end{array}$ & $\begin{array}{l}2.783 \\
(3.35)\end{array}$ & $\begin{array}{l}3.294 \\
(3.79)\end{array}$ & $\begin{array}{l}0.751 \\
(1.15)\end{array}$ & $\begin{array}{l}4.131 \\
(4.31)\end{array}$ & $\begin{array}{l}2.866 \\
(3.73)\end{array}$ & $\begin{array}{l}3.141 \\
(3.25)\end{array}$ \\
\hline $\mathrm{P}_{\mathrm{t}-1}^{\mathrm{l}}$ & $\begin{array}{c}0.238 \\
(1.64)\end{array}$ & $\begin{array}{l}0.237 \\
(1.56)\end{array}$ & $\begin{array}{c}0.398 * * \\
(3.35)\end{array}$ & $\begin{array}{c}0.437^{* *} \\
(3.58)\end{array}$ & $\begin{array}{l}0.256 * \\
(1.94)\end{array}$ & $\begin{array}{c}0.211 \\
(1.45)\end{array}$ & $\begin{array}{c}0.034 \\
(0.25)\end{array}$ & $\begin{array}{c}0.340 * * \\
(2.76)\end{array}$ & $\begin{array}{c}0.286 * * \\
(2.53)\end{array}$ & $\begin{array}{c}0.343^{* *} \\
(2.72)\end{array}$ \\
\hline $\mathrm{P}_{\mathrm{t}}^{\mathrm{c}}-\mathrm{P}_{\mathrm{t}-1}^{\mathrm{c}}$ & $\begin{array}{l}0.224 \\
(1.21)\end{array}$ & $\begin{array}{c}0.056 \\
(0.42)\end{array}$ & $\begin{array}{c}0.298^{*} \\
(1.70)\end{array}$ & $\begin{array}{l}0.292 * \\
(2.30)\end{array}$ & $\begin{array}{c}0.374 * * \\
(2.90)\end{array}$ & $\begin{array}{c}0.239 * * \\
(2.59)\end{array}$ & $\begin{array}{c}0.654 * * \\
(8.61)\end{array}$ & $\begin{array}{l}0.152 \\
(1.15)\end{array}$ & $\begin{array}{c}0.355^{* *} \\
(4.61)\end{array}$ & $\begin{array}{c}0.185^{*} \\
(1.81)\end{array}$ \\
\hline $\mathrm{P}_{\mathrm{t}-1}^{\mathrm{c}}$ & $\begin{array}{l}0.128 \\
(0.68)\end{array}$ & $\begin{array}{l}-0.041 \\
(-0.30)\end{array}$ & $\begin{array}{l}-0.131 \\
(-0.92)\end{array}$ & $\begin{array}{l}0.264 * \\
(1.92)\end{array}$ & $\begin{array}{c}0.323 * \\
(3.02)\end{array}$ & $\begin{array}{c}0.304^{* *} \\
(2.50)\end{array}$ & $\begin{array}{c}0.867 * * \\
(5.87)\end{array}$ & $\begin{array}{l}0.038 \\
(0.38)\end{array}$ & $\begin{array}{c}0.289 * * \\
(3.55)\end{array}$ & $\begin{array}{c}0.178 \\
(1.65)\end{array}$ \\
\hline Harvest & $\begin{array}{l}-0.087 \\
(-1.65)\end{array}$ & $\begin{array}{l}-0.103 \\
(-1.95)\end{array}$ & $\begin{array}{c}-0.096 * \\
(-1.80)\end{array}$ & $\begin{array}{l}-0.053 \\
(-1.15)\end{array}$ & $\begin{array}{l}-0.013 \\
(-0.24)\end{array}$ & $\begin{array}{c}-0.089 * \\
(-1.76)\end{array}$ & $\begin{array}{c}-0.123 * * \\
(-3.34)\end{array}$ & $\begin{array}{l}-0.090 \\
(-1.54)\end{array}$ & $\begin{array}{c}-0.076^{*} \\
(-1.67)\end{array}$ & $\begin{array}{l}-0.042 \\
(-0.65)\end{array}$ \\
\hline Draught & $\begin{array}{c}0.022 \\
(0.19)\end{array}$ & $\begin{array}{l}-0.012 \\
(-0.09)\end{array}$ & $\begin{array}{l}-0.115 \\
(-1.62)\end{array}$ & & $\begin{array}{l}-0.075 \\
(-1.08)\end{array}$ & $\begin{array}{l}-0.030 \\
(-0.56)\end{array}$ & $\begin{array}{c}0.017 \\
(0.36)\end{array}$ & $\begin{array}{l}-0.090 \\
(-1.28)\end{array}$ & $\begin{array}{c}-0.092 * \\
(-1.72)\end{array}$ & $\begin{array}{c}-0.122 * \\
(-1.78)\end{array}$ \\
\hline $\begin{array}{l}\text { Water } \\
\text { shortage } \\
\text { Flood }\end{array}$ & $\begin{array}{c}-0.101 * \\
(-1.80)\end{array}$ & $\begin{array}{c}-0.095^{*} \\
(-1.68)\end{array}$ & $\begin{array}{c}-0.103^{*} \\
(-1.98) \\
0.015 \\
(0.26)\end{array}$ & & $\begin{array}{c}-0.110 * \\
(-2.39)\end{array}$ & $\begin{array}{c}-0.082 \\
(-1.51) \\
-0.096 \\
(-0.92)\end{array}$ & $\begin{array}{c}-0.131 * * \\
(-3.46) \\
-0.004 \\
(-0.11)\end{array}$ & $\begin{array}{c}-0.081 \\
(-1.39) \\
0.026 \\
(0.43)\end{array}$ & $\begin{array}{c}-0.117 * * \\
(-2.55) \\
0.164 * * \\
(2.93)\end{array}$ & $\begin{array}{c}-0.089 * \\
(-1.85)\end{array}$ \\
\hline F-value & 2.73 & 2.37 & 4.36 & 4.93 & 6.02 & 3.85 & 16.42 & 3.08 & 7.88 & 4.40 \\
\hline $\mathrm{R}^{2}$ & 0.3123 & 0.2783 & 0.3790 & 0.2955 & 0.4294 & 0.3801 & 0.7284 & 0.3015 & 0.5245 & 0.3409 \\
\hline
\end{tabular}

"** the significant at $\mathbf{Q}=5 \%$, and "**" the significant at $\mathbf{Q}=1 \%$

(a) M1 = Serey Sophorn market, M2 = Bung Chhouk market, M3 = Leu market (K. Chhnang, M4 = Deum Kor market, M5 = Leu market (K. Som), M6 = Samaki market, M7 = Doun Keo market, M8 = Takhmao market, M9= Nak Loeung market, M10 = Bung Kok market, M11 = Leu market (Siem Reap).

(b) Figures in parentheses are t-value

have significantly been under the influence of change in price of Deum Kor. For instance, one percent changes at Deum Kor leads to change in 0.65 percent at Takhmao in respond. We observe that among the above markets, the connection between Takhmao and Deum Kor tends to be relatively stronger but in contrast, Serey Sophorn, Bung Chhouk, and Nak Loeung market appear to be independently separated in long run with Deum Kor for radish.

There are certain influences from harvest, draught, water shortage, and flood period on radish price forma- tion at certain local markets studied. Leu (Kampong Chhnang), Doun Keo, and Takhmao market came significantly under the influence of harvest season while Leu (Siem Reap) encountered the influence of draught and Bung Kok was under the influence of flood. The impact of harvest season, it can be concluded that these markets are located in the radish production areas. Moreover, the influence of water shortage has significantly impacted on Serey Sophorn, Bung Chhouk, Leu (Kampong Chhnang), Samaki, Takhmao, Bung Kok, and Leu (Siem Reap). 
Table 7. Results of Estimated Coefficients of Tomato Price Formation Equation for 10 local markets

\begin{tabular}{|c|c|c|c|c|c|c|c|c|c|c|}
\hline Variables & $\mathrm{M}^{\mathrm{a}}$ & M2 & M3 & M5 & M6 & M7 & M8 & M9 & M10 & M11 \\
\hline Intercept & $\begin{array}{c}0.156 \\
(0.11)^{b}\end{array}$ & $\begin{array}{l}1.755 \\
(1.05)\end{array}$ & $\begin{array}{l}1.694 \\
(2.24)\end{array}$ & $\begin{array}{l}1.672 \\
(1.83)\end{array}$ & $\begin{array}{l}0.541 \\
(0.77)\end{array}$ & $\begin{array}{l}1.892 \\
(2.37)\end{array}$ & $\begin{array}{l}1.399 \\
(2.68)\end{array}$ & $\begin{array}{c}1.849 \\
(2.43)\end{array}$ & $\begin{array}{l}2.194 \\
(3.17)\end{array}$ & $\begin{array}{l}0.512 \\
(0.76)\end{array}$ \\
\hline $\mathrm{P}_{\mathrm{t}-1}^{\mathrm{l}}$ & $\begin{array}{c}0.781^{* *} \\
(6.31)\end{array}$ & $\begin{array}{c}0.761^{* *} \\
(5.87)\end{array}$ & $\begin{array}{c}0.724^{* *} \\
(7.11)\end{array}$ & $\begin{array}{c}0.706^{* *} \\
(6.87)\end{array}$ & $\begin{array}{c}0.531 * * \\
(4.08)\end{array}$ & $\begin{array}{c}0.568 * * \\
(4.09)\end{array}$ & $\begin{array}{c}0.365 * * \\
(2.91)\end{array}$ & $\begin{array}{c}0.669 * * \\
(5.55)\end{array}$ & $\begin{array}{c}0.549 * * \\
(4.36)\end{array}$ & $\begin{array}{c}0.469 * * \\
(3.80)\end{array}$ \\
\hline $\mathrm{P}^{c}{ }_{\mathrm{t}}^{-} \mathrm{P}_{\mathrm{t}-1}^{c}$ & $\begin{array}{c}0.111 \\
(0.80)\end{array}$ & $\begin{array}{l}-0.093 \\
(-0.50)\end{array}$ & $\begin{array}{c}0.256^{* *} \\
(4.11)\end{array}$ & $\begin{array}{l}0.283^{*} \\
(1.42)\end{array}$ & $\begin{array}{c}0.558 * * \\
(5.42)\end{array}$ & $\begin{array}{c}0.304 * * \\
(3.82)\end{array}$ & $\begin{array}{c}0.481 * * \\
(9.33)\end{array}$ & $\begin{array}{c}0.172 * * \\
(2.56)\end{array}$ & $\begin{array}{c}0.215^{* * *} \\
(4.50)\end{array}$ & $\begin{array}{c}0.360 * * \\
(4.13)\end{array}$ \\
\hline $\mathrm{P}_{\mathrm{t}-1}^{\mathrm{c}}$ & $\begin{array}{l}0.196 \\
(1.21)\end{array}$ & $\begin{array}{l}-0.001 \\
(-0.00)\end{array}$ & $\begin{array}{c}0.046 \\
(0.49)\end{array}$ & $\begin{array}{l}0.067 \\
(0.54)\end{array}$ & $\begin{array}{c}0.395 * * \\
(3.14)\end{array}$ & $\begin{array}{l}0.173^{*} \\
(2.03)\end{array}$ & $\begin{array}{c}0.448 * * \\
(5.06)\end{array}$ & $\begin{array}{c}0.082 \\
(1.19)\end{array}$ & $\begin{array}{c}0.155^{* *} * \\
(2.66)\end{array}$ & $\begin{array}{c}0.457^{* *} * \\
(4.04)\end{array}$ \\
\hline Harvest & $\begin{array}{c}-0.173^{* *} \\
(-3.81)\end{array}$ & $\begin{array}{c}-0.182^{* *} \\
(-4.07)\end{array}$ & $\begin{array}{c}-0.133^{* *} \\
(-3.16)\end{array}$ & $\begin{array}{c}-0.184^{* *} \\
(-4.64)\end{array}$ & $\begin{array}{c}-0.157 * * \\
(-4.57)\end{array}$ & $\begin{array}{c}-0.119 * * \\
(-2.79)\end{array}$ & $\begin{array}{l}-0.036 \\
(-1.08)\end{array}$ & $\begin{array}{c}-0.157 * * \\
(-3.30)\end{array}$ & $\begin{array}{l}-0.081 \\
(-1.83)\end{array}$ & $\begin{array}{c}-0.118^{* *} \\
(-3.17)\end{array}$ \\
\hline Draught & $\begin{array}{c}0.044 \\
(0.42)\end{array}$ & $\begin{array}{c}0.035 \\
(0.34)\end{array}$ & $\begin{array}{c}0.020 \\
(0.38)\end{array}$ & & $\begin{array}{l}-0.009 \\
(-0.18)\end{array}$ & $\begin{array}{l}-0.028 \\
(-0.66)\end{array}$ & $\begin{array}{c}0.018 \\
(0.52)\end{array}$ & $\begin{array}{l}-0.002 \\
(-0.03)\end{array}$ & $\begin{array}{l}0.008 \\
(0.17)\end{array}$ & $\begin{array}{c}0.006 \\
(0.12)\end{array}$ \\
\hline $\begin{array}{l}\text { Water } \\
\text { shortage } \\
\text { Flood }\end{array}$ & $\begin{array}{l}0.067 \\
(1.07)\end{array}$ & $\begin{array}{l}0.016 \\
(0.29)\end{array}$ & $\begin{array}{l}-0.011 \\
(-0.18) \\
-0.024 \\
(-0.56)\end{array}$ & & $\begin{array}{c}0.013 \\
(0.30)\end{array}$ & $\begin{array}{c}0.042 \\
(0.80) \\
-0.007 \\
(-0.09)\end{array}$ & $\begin{array}{c}0.019 \\
(0.59) \\
-0.032 \\
(-1.14)\end{array}$ & $\begin{array}{c}0.012 \\
(0.20) \\
-0.053 \\
(-1.10)\end{array}$ & $\begin{array}{c}0.016 \\
(0.30) \\
-0.037 \\
(-0.86)\end{array}$ & $\begin{array}{c}0.013 \\
(0.30)\end{array}$ \\
\hline $\begin{array}{l}\text { F-value } \\
\mathrm{R}^{2}\end{array}$ & $\begin{array}{c}10.36 \\
0.6223\end{array}$ & $\begin{array}{c}9.62 \\
0.6103\end{array}$ & $\begin{array}{c}24.00 \\
0.7706\end{array}$ & $\begin{array}{c}19.41 \\
0.6229\end{array}$ & $\begin{array}{c}31.07 \\
0.7952\end{array}$ & $\begin{array}{c}15.20 \\
0.7074\end{array}$ & $\begin{array}{c}49.62 \\
0.8901\end{array}$ & $\begin{array}{c}18.17 \\
0.7178\end{array}$ & $\begin{array}{c}26.19 \\
0.7857\end{array}$ & $\begin{array}{c}29.67 \\
0.7773\end{array}$ \\
\hline
\end{tabular}

"*" the significant at $\mathbf{Q}=5 \%$, and "**" the significant at $\mathbf{Q}=1 \%$

(a) M1 = Serey Sophorn market, M2 = Bung Chhouk market, M3 = Leu market (K. Chhnang, M4 = Deum Kor market, M5 = Leu market (K. Som), M6 = Samaki market, M7 = Doun Keo market, M8 = Takhmao market, M9= Nak Loeung market, M10 = Bung Kok market, M11 = Leu market (Siem Reap).

(b) Figures in parentheses are t-value

\section{- Tomato}

Table 7 shows that a number of regional markets, including Leu (Kampong Chhnang), Samaki, Doun Keo, Takhmao, Nak Loeung, Bung Kok, and Leu (Siem Reap) are well connected in the long run with Deum Kor. These markets came under the influence of the change in price at Deum Kor to form their current tomato price formation. The degree of influences varies basing on the markets and region where the markets are located. However the result shows that Serey Sophorn, Bung Chhouk, and Leu (Kampong Som) are poorly connected in the long run with the Deum Kor.

In addition, it is seen that most of markets studied have faced the influence stemming from harvest season in forming their current prices. Those markets are of Serey Sophorn, Bung Chhouk, Leu (Kampong Chhnang), Leu (Kampong Som), Samaki, Doun Keo, Nak Loeung, Bung Kok, and Leu (Siem Reap). One may induce that these markets are located in tomato production areas.

\section{CONCLUSION}

From the empirical results based on Timmer's regression model, we found support for the hypothesis that Deum Kor, the central market is the major consumption and distribution center of vegetables in Cambodia from which information flow out to other regional markets. The flow of information eventually creates a phenomenon of short-run and/or long-run connection between the markets spatially. Takhmao has a very good connection with Dem Kor in the short and long run for all commodities selected while Serey Sophorn and Bung Chhouk tend to be independent. The good connection is because Takhmao is one of markets located in the main production area, connected by good road and communication networks with Deum Kor in addition to near in distance. So, products and information transmission flow in a convenient, cheaper, and faster way. In contrast, Serey Sophorn and Bung Chhouk located in the north-west part of the country, far in distance from Deum Kor are poorly interrelated in short and long run for almost commodities selected. Thus, their additional sources of supplies may derive from Thai markets, which stay close to their location.

In conclusion, the degree of vegetable market connection varies depending on characteristics of vegetables and the regions where markets are located, characteristics of markets, and road and communication system, which reflex the availability of market information.

\section{POLICY IMPLICATION}

Seeing their importance in marketing performance, improving road and communication network and market structure is necessary in the aim of reducing the transport costs and improving the inefficiency of market connection in addition to laying down market based program and policies in order to facilitate marketing performance and promote domestic agricultural products.

\section{REFERENCES}

A. J. Aulton, C. T. Ennew and A. J. Rayner 1997 Efficiency Tests of Futures Markets for UK Agricultural Commodities. Journal of Agricultural Economics, 48(3): 408-424

Barry K. Goodwin and Ted C. Schroeder 1991 Cointegration Tests and Spatial Price Linkages in Regional Cattle Markets. Am. J. Agric. Econ. 73(2): 452-464

Carol Alexander and John Wyeth 1994 Cointegration and Market 
Integration: An Application to the Indonesian Rice Market. The Journal of Development Studies, 30(2): 303-328

Chan Sipana and Paule Moustier 2004 Socio-Economic Strategies and Results of Vegetable Traders in Phnom Penh (Cambodia). Sustainable Development of Peri-urban Agriculture in South-East Asia Project (Cambodia, Loa, and Vietnam), www.avrdc.org/susper (retrieved 9 June, 2007)

Eugene F. Fama 1976 Foundations of Finance. Basic Books, Inc., New York. pp. 133-168

Francesco GOLETTI, Raisuddin AHMED, and Naser FARID 1995 Structural Determinants of Market Integration: The Case of Rice Markets in Bangladesh. The Developing Economies, XXXIII-2: 185-202

Johnson, D. G. 1983 Policies and Performance in Soviet Agriculture. In "Prospects for Soviet Agriculture in the 1980s", ed. by D.G. Johnson and K. M. Brooks. Indiana University Press

Karl D. Skold and Victor N. Popov 1990 Technical Efficiency in Crop Production: An Application to the Stavropol Regions, USSR. Center of Agricultural and Rural Development, Iowa State University, USA

Martin Ravallion 1986 Testing Market Integration. Am. J. Agric. Econ. 68(1): 102-109
Paul J. Heytens 1986 Testing Market Integration. Food Research Institute Studies, $\mathbf{X X ( 1 ) : 2 5 - 4 1}$

Prabhakara RAO J. V. 1985 Marketing Efficiency in Agricultural Products: A Case Study of Cotton in Guntur District in Andhra Pradesh. Himalaya Publishing House, Bombay, India, pp. 185-253

Raghbendra Jha, K. V. Bhanu Murthy, and Anurag Sharma 2005 Market Integration in Wholesale Rice Markets in India. ASARC Working Paper, 2005/03. ASARC, Australian National University, Canberra ACT 0200, Australia

Sophal Ear 1995 Cambodia's Economic Development and History: A Contribution to the Study of Cambodia's Economy. Undergraduate Economics Honors Thesis, University of California, USA

Steven T. Buccola 1985 Pricing Efficiency in Centralized and Noncentralized Markets. Am. J. Agric. Econ., 67(3): $583-590$

Steven T. Buccola 1989 Pricing Efficiency in Agricultural Markets: Issues, Methods, and Results. Western Journal of Agricultural Economics, 14(1): 111-121

Timmer, C. P. 1987 The Corn Economy of Indonesia. Ithaca: Cornell University press. 